\title{
Infection of Monocyte/Macrophages by Human T Lymphotropic Virus Type III
}

David D. Ho, Teresa R. Rota, and Martin S. Hirsch

Infectious Disease Unit, Massachusetts General Hospital and Harvard Medical School, Boston, Massachusetts 02114

\begin{abstract}
Normal blood-derived monocyte/macrophages were found to be susceptible to infection in vitro by human $\mathbf{T}$ lymphotropic virus type III (HTLV-III), the etiologic agent of the acquired immunodeficiency syndrome. In addition, HTLV-III was recovered from monocyte/macrophages of patients infected with this virus. The above findings raise the possibility that HTLV-III-infected monocyte/macrophages may serve as a vehicle for the dissemination of virus to target organs and as a reservoir for viral persistence, as has been shown for other lentiviruses including visna virus and caprine arthritis encephalitis virus.
\end{abstract}

\section{Introduction}

Human T lymphotropic virus type III (HTLV-III) ${ }^{1}$ (1), also known as lymphadenopathy-associated virus (2), is the etiologic agent of the acquired immunodeficiency syndrome (AIDS). This retrovirus is tropic and cytopathic for helper-inducer (T4) lymphocytes (3), resulting in profound defects in cell-mediated immunity (4). In addition, HTLV-III is neurotropic and capable of directly causing a number of neurologic syndromes $(5,6)$. Several recent preliminary reports suggest that HTLV-III may also infect monocytes or macrophages. Two groups have noted that the human monocytic cell line, U-937, was susceptible to HTLV-III infection in vitro $(7,8)$. Retroviral particles resembling HTLV-III have also been detected by electron microscopy in macrophages in lymph node (9) and brain (10) of HTLV-III infected individuals.

Whether monocyte/macrophages are susceptible to HTLVIII infection has important implications. Recent studies suggest that HTLV-III is closely related to a group of nononcogenic, cytopathic retroviruses (lentiviruses), including visna virus, caprine arthritis encephalitis virus, and possibly equine infectious anemia virus (11-13). For these lentiviruses, the major target of infection is the monocyte/macrophage, which serves as a vehicle for the dissemination of virus to other sites and as a reservoir for viral persistence $(14,15)$. We, therefore, studied the susceptibility of normal human monocyte/macrophages to HTLV-III

Address correspondence to Dr. Ho.

Received for publication 27 December 1985.

1. Abbreviations used in this paper: AIDS, acquired immunodeficiency syndrome; HTLV-III, human T lymphotropic virus type III; RT, reverse transcriptase.

J. Clin. Invest.

(c) The American Society for Clinical Investigation, Inc. 0021-9738/86/05/1712/04 \$1.00

Volume 77, May 1986, 1712-1715 infection in vitro. In addition, we attempted to isolate HTLVIII from monocyte/macrophages obtained from peripheral blood of infected patients.

\section{Methods}

Study subjects. Six healthy laboratory workers donated blood for the studies described below. These individuals were seronegative for HTLVIII as determined by enzyme-linked immunosorbent assay and immunoblot (Western) technique (16). Four homosexual men who were seropositive for HTLV-III donated blood for virus isolation studies. Two were patients with AIDS-related complex, and two were asymptomatic. All were HTLV-III positive on prior blood cultures.

Cells and viruses. Normal peripheral blood mononuclear cells were obtained on Ficoll-Hypaque (Ficoll, Sigma Chemical Co., St. Louis, MO; Hypaque, Winthrop Laboratories, New York, NY) density gradients. H9 cells and HTLV-IIIB (17) were kindly provided by R. Gallo (National Cancer Institute, Bethesda, MD).

Infection of normal monocyte/macrophages. Two $25-\mathrm{cm}^{2}$ plastic flasks (Falcon Labware, Oxnard, CA) were each inoculated with $25 \times 10^{6}$ normal peripheral blood mononuclear cells in $5 \mathrm{ml}$ RPMI 1640 medium supplemented with Hepes buffer $(10 \mathrm{mM})$, L-glutamine $(2 \mathrm{mM})$, penicillin (250 U/ml), streptomycin $(250 \mu \mathrm{g} / \mathrm{ml})$, and fetal calf serum (20\%). In addition, four 8-well plastic slide-culture chambers (LAB-TEK, Naperville, IL) were also inoculated with normal peripheral blood mononuclear cells at $1 \times 10^{6} \mathrm{cells} / \mathrm{cm}^{2}$. The cells were not activated with mitogens or interleukin 2. On days 1 and 2, nonadherent cells and supernatant fluids were removed from the flasks and slide-culture chambers. The plasticadherent cells were then washed three times with phosphate-buffered saline before being replenished with fresh medium. On day 3 , the remaining plastic-adherent cells were subjected to two episodes of complement-mediated $\mathrm{T}$ cell lysis using OKT3 monoclonal antibody (Ortho Diagnostic Systems, Inc., Raritan, NJ) and rabbit complement (see below). On day 4 , one of the two $25-\mathrm{cm}^{2}$ flasks and two of the four slideculture chambers were then inoculated with cell-free HTLV-IIIB at a dose of $8 \times 10^{2} 50 \%$ tissue culture infective doses $\left(\operatorname{TCID}_{50}\right) / \mathrm{cm}^{2}$. The other corresponding flask and slide-culture chambers were used as controls and were mock-infected with virus-free $\mathrm{H} 9$ culture supernatant fluid. Subsequently, complete medium changes were performed every 3-4 d. Between days 12 and 17 , the $25-\mathrm{cm}^{2}$ cultures were assayed for reverse transcriptase (RT) activity and infectious virus, while the slide-chamber cultures were exàmined for expression of HTLV-III antigens and OKT3, OKB7, 0KM5, and OKM1 (all obtained from Ortho Diagnostic Systems) markers by a fixed-cell indirect immunofluorescence technique. A total of four such experiments were conducted.

Isolation of HTLV-III from monocyte/macrophages of infected persons. Peripheral blood mononuclear cells $\left(50 \times 10^{6}\right)$ from four patients were separately seeded into $25-\mathrm{cm}^{2}$ flasks in $5 \mathrm{ml}$ RPMI 1640 medium with supplements described above but without mitogens or interleukin 2. Additional cells were also seeded into 8-well slide-culture chambers at a density of $2 \times 10^{6} / \mathrm{cm}^{2}$. On day 1 , nonadherent cells were removed, and the attached cells were washed extensively with phosphate-buffered saline. Washings were repeated on day 2 , followed by two courses of complement-mediated $T$ cell lysis (see below). On day 3, after three more washings, $5 \times 10^{6}$ normal peripheral blood mononuclear cells from 
HTLV-III seronegative subjects, preactivated with phytohemagglutinin $(10 \mu \mathrm{g} / \mathrm{ml}$; Sigma Chemical Co.) and pretreated with Polybrene $(2 \mu \mathrm{g} /$ $\mathrm{ml}$; Sigma Chemical Co.), were cocultivated with patients' plastic-adherent, $\mathrm{T}$ cell-depleted monocyte/macrophages in the $25-\mathrm{cm}^{2}$ flasks. The cells in the slide-culture chambers were fixed in acetone and examined for phenotypic expression of OKT3, OKB7, OKM5, and OKM1 markers. Subsequently, the cocultures, maintained in medium containing $10 \%$ interleukin 2 (Electro-Nucleonics, Inc., Fairfield, MD), were serially monitored for RT activity and HTLV-III-specific antigen expression. As controls, $2 \times 10^{6}$ of the nonadherent mononuclear cells removed on day 1 were also subjected twice to complement-mediated $T$ cell lysis. The remaining cells and debris, after extensive washings, were also cocultured with preactivated normal peripheral blood mononuclear cells $\left(5 \times 10^{6}\right)$. In parallel, these cultures were also assayed sequentially for RT activity.

Reverse transcriptase assay. Viruses in cell-free supernatant fluids (3 $\mathrm{ml}$ ) were precipitated with polyethylene glycol $(1.5 \mathrm{ml})$, and the particulate reverse transcriptase activity was assayed as previously described $(18,19)$.

Indirect immunofluorescence assay. HTLV-III antigen expression was assessed using a human immune serum, which is strongly positive for HTLV-III antibodies as tested by enzyme-linked immunosorbent assay and immunoblot technique. Expression of pan-T cell marker, B cell marker, and monocyte markers were determined by using OKT3, OKB7, OKM5, and OKM1 monoclonal antibodies. The fixed-cell indirect immunofluorescence tests were performed as previously described $(18,20)$.

Virus yield assay. Cell-free culture supernatant fluids $(1 \mathrm{ml})$ were assayed for infectious virus on $\mathrm{H} 9$ cells $\left(2 \times 10^{6}\right)$ pretreated with Polybrene $(2 \mu \mathrm{g} / \mathrm{ml})$. Presence of HTLV-III was demonstrated by characteristic cytopathic effects $(17,18)$, RT activity, and specific viral immunofluorescence.

Complement-mediated lysis of $T$ cells. Complement-mediated $\mathrm{T}$ cell lysis was performed using OKT3 monoclonal antibody and rabbit complement (Pel-Freeze Biologicals, Rogers, AR) as previously described (21).

\section{Results}

Infection of monocyte/macrophages. Cell viability and morphology were not significantly altered by the inoculation of HTLV-III. That the plastic-adherent cells were monocyte/macrophages was shown by positive staining with OKM1 (90\%) and OKM5 (80\%) monoclonal antibodies and no staining with OKB7 or OKT3 monoclonal antibodies. Results of HTLV-III expression in these monocyte/macrophages are shown in Table I. In all four experiments, infectious virus and RT activity $(2,600$ to $23,000 \mathrm{cpm} / \mathrm{ml}$ ) were detected in cultures previously inoculated with HTLV-III. In experiments 1,3 , and 4, HTLV-III antigens were also demonstrated in $1-5 \%$ of monocyte/macrophages by indirect immunofluorescence, although the intensity of fluorescence was low. In contrast, the control cultures were completely negative for RT activity, viral antigens, and infectious virus. These findings are consistent with low-level HTLV-III replication in the normal, blood-derived monocyte/macrophages. Similar results were also obtained using a fresh clinical isolate of HTLVIII instead of the laboratory strain, HTLV-IIIB (data not shown).

Isolation of HTLV-III from monocyte/macrophages of infected patients. After extensive washings and two courses of complement-mediated $\mathrm{T}$ cell lysis, the patients' plastic-adherent cells were found to be OKT3-, OKB7-, OKM5+ (80\%), and OKM1 $+(90 \%)$ by immunofluorescence. Cocultivation of these cells with normal peripheral blood mononuclear cells resulted in development of RT activity $>10^{5} \mathrm{cpm} / \mathrm{ml}$ in three of four cultures (Fig. 1). These three viral isolates were confirmed as HTLV-III by specific immunofluorescence on days 15 and 19 of culture. To control for the possibility that the above findings were due to minor $\mathrm{T}$ cell contamination, we also cultured the nonadherent, $T$ cell-rich mononuclear cells removed on day 1 and subjected to two consecutive treatments of complementmediated T cell lysis. All four of these cultures were RT-negative. These results indicate that the three isolates derived from the plastic-adherent cells were indeed harbored within the monocyte/ macrophage population in the patients.

\section{Discussion}

We have shown that normal, blood-derived monocyte/macrophages can be infected by HTLV-III in vitro. The level of virus replication, however, appears to be low compared with the levels detected in $\mathrm{H} 9$ cells or normal peripheral blood lymphocytes. It is unlikely that contamination by residual $\mathrm{T}$ lymphocytes accounted for our finding because of the following reasons: extensive washings of the plastic-adherent cells, $\sim 2 \mathrm{wk}$ of in vitro culture without mitogens or interleukin 2 , two consecutive courses of complement-mediated lysis using OKT3 monoclonal antibody, and the lack of any immunofluorescent staining using OKT3 monoclonal antibody. The plastic-adherent cells were shown to be monocyte/macrophages by their strong, $80-90 \%$ immunofluorescence with both OKM1 and OKM5 monoclonal antibodies. OKM1 monoclonal antibody also binds to granulocytes and null cells, and OKM5 monoclonal antibody also reacts with platelets. However, only monocyte/macrophages are

Table I. Summary of Experiments Demonstrating HTLV-III Infection of Normal, Blood-derived Monocyte/Macrophages

\begin{tabular}{|c|c|c|c|c|c|c|c|c|c|c|c|c|}
\hline \multirow[b]{3}{*}{ HTLV-III expression } & \multicolumn{4}{|l|}{ Experiment 1} & \multirow{2}{*}{\multicolumn{2}{|c|}{$\begin{array}{l}\text { Experiment } 2 \\
\text { Day } 12\end{array}$}} & \multirow{2}{*}{\multicolumn{2}{|c|}{$\begin{array}{l}\text { Experiment } 3 \\
\text { Day } 14\end{array}$}} & \multicolumn{4}{|c|}{ Experiment 4} \\
\hline & \multicolumn{2}{|l|}{ Day 12} & \multicolumn{2}{|l|}{ Day 17} & & & & & \multicolumn{2}{|l|}{ Day 12} & \multicolumn{2}{|l|}{ Day 17} \\
\hline & A & B & $\mathbf{A}$ & B & $\mathbf{A}$ & B & A & B & A & B & $\mathbf{A}$ & B \\
\hline $\mathrm{RT}$ activity $(\mathrm{cpm} / \mathrm{ml})$ & $2.3 \times 10^{4}$ & 0 & $2.6 \times 10^{3}$ & 0 & $8 \times 10^{3}$ & 0 & $1 \times 10^{4}$ & 0 & $7.5 \times 10^{3}$ & 0 & $2.8 \times 10^{3}$ & 0 \\
\hline Antigen detection* & + & - & + & - & - & - & + & - & + & - & + & - \\
\hline Virus yield & + & - & + & - & + & - & + & - & + & - & + & - \\
\hline \multicolumn{13}{|l|}{ Cell phenotype } \\
\hline OKT3, OKB7 & - & - & - & - & - & - & - & - & - & - & - & - \\
\hline OKM1, OKM5 & + & + & + & + & + & + & + & + & + & + & + & + \\
\hline
\end{tabular}

A, Cultures inoculated with HTVL-III. B, Control cultures. * By indirect immunofluorescence technique. 


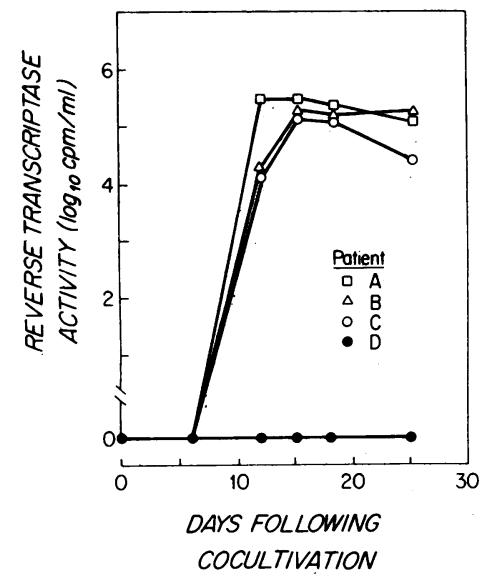

Figure 1. Sequential reverse transcriptase activities detected in three of four cocultures of patients' monocyte/macrophages with normal peripheral blood mononuclear cells.

OKM1+ and OKM5+ $(22,23)$. Therefore, it appears that normal monocyte/macrophages are susceptible to HTLV-III infection in vitro.

Levy and colleagues (24) have anecdotally reported the isolation of AIDS virus from macrophages of patients with AIDS. Here, we have also shown the isolation of HTLV-III from OKM1+ and OKM5+ plastic-adherent cells derived from blood of three patients who are known to be infected by the virus. This finding is unlikely to be the result of $T$ cell contamination, because the immunofluorescent staining of cultured cells with OKT3 monoclonal antibody was negative, and we were unable to isolate HTLV-III from nonadherent, T cell-rich peripheral blood mononuclear cells following two courses of complementmediated lysis using OKT3 monoclonal antibody. Therefore, we conclude that monocyte/macrophages from infected individuals can harbor HTLV-III in vivo.

The infection of monocyte/macrophages by HTLV-III in vitro and in vivo has important implications. Monocyte/macrophages may serve as an important reservoir for the persistence of HTLV-III in infected individuals. For the related lentiviruses, visna and caprine arthritis encephalitis viruses, latently infected monocytes and their precursors in the bone marrow are believed to be the major reservoir of infectious virus and the principal site for viral persistence $(14,25)$. In addition, HTLV-III infected monocyte/macrophages may function as a vehicle in the dissemination of the virus to target organs. This may also be similar to visna virus and caprine arthritis encephalitis virus infections, where latently-infected monocytes can deliver the viruses to lungs, central nervous system, and joints. Subsequently, with the differentiation of monocytes to macrophages, active viral replication occurs, resulting in inflammation and disease at those sites $(12,14)$. Perhaps, HTLV-III enters the central nervous system in a similar fashion, with the monocyte serving as the "Trojan horse". The terminal differentiation of the monocyte may then trigger HTLV-III replication and release, which in turn can lead to inflammation and destructive changes in the brain. Further studies of the interactions between HTLV-III and monocyte/ macrophage should lead to a better understanding of the pathogenesis of AIDS and other HTLV-III-related disorders.

\section{Acknowledgments}

We thank R. Schooley and J. Kaplan for helpful discussions and J. Steele for manuscript preparation.

Dr. Ho is a recipient of the Clinical Investigator Award from National Institutes of Health. This work was also supported by grant CA35020 from National Institutes of Health.

\section{References}

I. Gallo, R. C., S. Z. Salahuddin, M. Popovic, G. M. Shearer, M. Kaplan, B. F. Haynes, T. J. Palker, R. Redfield, J. Oleske, B. Safai, G. White, P. Foster, and P. D. Markham. 1984. Frequent detection and isolation of cytopathic retroviruses (HTLV-III) from patients with AIDS and at risk for AIDS. Science (Wash. DC). 224:500-503.

2. Barre-Sinoussi, F., J. C. Chermann, F. Rey, M. T. Nugeyre, S. Chamaret, J. Gruest, C. Dauguet, C. Axler-Blin, F. Vezinet-Brun, C. Rouzioux, W. Rozenbaum, and L. Montagnier. 1983. Isolation of a T-lymphotropic retrovirus from a patient at risk for acquired immune deficiency syndrome (AIDS). Science (Wash. DC). 220:868-871.

3. Klatzmann, D., F. Barre-Sinoussi, M. T. Nugeyre, C. Dauguet, E. Vilmer, C. Griscelli, F. Brun-Vezinet, C. Rouzious, J. C. Gluckman, J. C. Chermann, and L. Montagnier. 1984. Selective tropism of lymphadenopathy associated virus (LAV) for helper-inducer T lymphocytes. Science (Wash. DC). 225:59-62.

4. Bowen, D. L., H. C. Lane, and A. S. Fauci. 1985. Immunopathogenesis of the acquired immunodeficiency syndrome. Ann. Intern. Med. 103:704-709.

5. Shaw, G. M., M. E. Harper, B. H. Hahn, L. G. Epstein, D. C. Gajdusek, R. W. Price, B. A. Navia, C. K. Petito, C. J. O'Hara, J. E. Groopman, E-S Cho, J. M. Oleske, F. Wong-Staal, and R. C. Gallo. 1985. HTLV-III infection in brains of children and adults with AIDS encephalopathy. Science (Wash. DC). 227:177-182.

6. Ho, D. D., T. R. Rota, R. T. Schooley, J. C. Kaplan, J. D. Allan, J. E. Groopman, L. Resnick, D. Felsenstein, C. A. Andrews, and M. S. Hirsch. 1985. Isolation of HTLV-III from cerebrospinal fluid and neural tissues of patients with neurologic syndromes related to the acquired immunodeficiency syndrome. N. Engl. J. Med. 313:1493-1497.

7. Dalgleish, A. G., P. C. L. Beverley, P. R. Clapham, D. H. Crawford, M. F. Greaves, and R. A. Weiss. 1984. The CD4 (T4) antigen is an essential component of the receptor for the AIDS retrovirus. Nature (Lond.). 312:763-767.

8. Levy, J. A., J. Shimabukuro, T. McHugh, C. Casavant, D. P. Stites, and L. S. Oshiro. 1985. AIDS-associated retroviruses (ARV) can productively infect other cells besides human $\mathrm{T}$ helper cells. Virology. 147:441-448.

9. Gyorkey, F., J. L. Melnick, J. G. Sinkovics, and P. Gyorkey. 1985. Retrovirus resembling HTLV in macrophages of patients with AIDS. Lancet. i: 106.

10. Epstein, L. G., L. R. Sharer, E.-S. Cho, M. Myenhofer, B. A Navia, and R. W. Price. 1984/1985. HTLV-III/LAV-like retrovirus particles in the brains of patients with AIDS encephalopathy. AIDS Research. $1: 447-454$.

11. Gonda, M. A., F. Wong-Staal, R. C. Gallo, J. E. Clements, O. Narayan, and R. V. Gilden. 1985. Sequence homology and morphologic similarity of HTLV-III and visna virus, a pathogenic lentivirus. Science (Wash. DC). 227:173-177.

12. Sonigo, P., M. Alizon, K. Staskus, D. Klatzmann, S. Cole, O. Danos, E. Retzel, P. Tiollais, A. Haase, and S. Wain-Hobson. 1985. Nucleotide sequence of the visna lentivirus: relationship to the AIDS virus. Cell. 42:369-382.

13. Chin, I.-M., A. Yaniv, J. E. Dahlberg, A. Gazit, S. F. Skuntz, S. R. Tronick, and S. A. Aaronson. 1985. Nucleotide sequence evidence for relationship of AIDS retrovirus to lentiviruses. Nature (Lond.). 317: 366-368.

14. Gendelman, H. E., O. Narayan, S. Molineaux, J. E. Clements, and Z. Ghotbi. 1985. Slow, persistent replication of lentiviruses: role of tissue macrophages and macrophage precursors in bone marrow. Proc. Natl. Acad. Sci. USA. 82:7086-7090.

15. Cheevers, W. P., and T. C. McGuire. 1985. Equine infectious anemia virus: immunopathogenesis and persistence. Rev. Infect. Dis. 7 : 83-88. 
16. Sarngadharan, M. G.; M. Popovic, L. Bruch, J. Schupbach, and R. C. Gallo. 1984. Antibodies reactive with human T-lymphotropic retroviruses (HTLV-III) in the serum of patients with AIDS. Science (Wash. DC). 224:506-508.

17. Popovic, M., M. G. Sarngadharan, E. Read, and R. C. Gallo. 1984. Detection, isolation and continuous production of cytopathic retroviruses (HTLV-III) from patients with AIDS and Pre-AIDS. Science (Wash. DC). 224:497-500.

18. Ho, D. D., R. T. Schooley, T. R. Rota, J. C. Kaplan, T. Flynn, S. Z. Salahuddin, M. A. Gonda, and M. S. Hirsch. 1984. HTLV-III in the semen and blood of a healthy homosexual man. Science (Wash. DC). 226:451-453.

19. Ho, D. D., T. R. Rota, and M. S. Hirsch. 1984. Infection of human endothelial cells by human T-lymphotropic virus type I. Proc. Natl. Acad. Sci. USA. 81:7588-7590.

20. Sandstrom, E., R. T. Schooley, D. D. Ho, R. Byington, M. G. Sarngadharan, M. E. MacLane, M. Essex, R. C. Gallo, and M. S. Hirsch.
1985. Detection of human anti-HTLV-III antibodies by indirect immunofluorescence using fixed cells. Transfusion (Paris). 4:308-312.

21. Carney, W. P., V: Iacoviello, and M. S. Hirsch. 1983. Functional properties of $\mathrm{T}$ lymphocytes and their subsets in cytomegalovirus mononucleosis. J. Immunol. 130:390-393.

22. Talle, M. A., P. E. Rao, E. Westberg, N. Allegar, M. Makowski, R. S. Mittler, and G. Goldstein. 1983. Patterns of antigenic expression on human monocytes as defined by monoclonal antibodies. Cell. Immunol. 78:83-99.

23. Breard, J., E. L. Reinherz, P. C. Kung, G. Goldstein, and S. F. Schlossman. 1980. A monoclonal antibody reactive with human peripheral blood monocytes. J. Immunol. 124:1943-1948.

24. Levy, J. A., L. S. Kaminsky, J. W. Morrow, K. Steimer, P. Luciw, D. Dina, J. Hoxie, and L. Oshiro. 1985. Infection by the retrovirus associated with the acquired immunodeficiency syndrome. Ann. Intern. Med. 103:694-699.

25. Narayan, O., and L. C. Cork. 1985. Lentiviral diseases of sheep and goats: chronic pneumonia leukoencephalomyelitis and arthritis. Rev. Infect. Dis. 7:89-98. 